\title{
Capital Gains Taxes and Asset Prices: The Impact of Tax Awareness and Procrastination
}

\author{
Version: July 2014 \\ Sebastian Eichfelder, Otto-von-Guericke-Universität Magdeburg \\ Mona Lau, Freie Universität Berlin and Ernst \& Young Berlin
}

\begin{abstract}
We argue that the impact of capital gains taxation on asset pricing depends on the tax awareness of market participants. While institutional investors should be generally wellinformed about tax regulations, private investors have only limited tax knowledge and resources. As a result, market reactions on tax law changes may be delayed if a considerable fraction of market participants is not fully tax-aware. In line with our argument, we find evidence that the introduction of a previously announced German flat tax on private capital gains in 2009 resulted in a temporarily strong and significant increase of trading volumes, daily returns and asset prices. Our research implies that tax law changes provide an opportunity for well-informed investors to generate arbitrage benefits. Corresponding to our estimate, the capital gains tax resulted in an increase demand for shares of $160 \%$ as well as in an price surplus of about $7.4 \%$ within the last two trading days 2008 .
\end{abstract}

Keywords - capital gains tax, asset pricing, tax awareness, tax arbitrage

JEL Classification - G1, H25, M41

- We are thankful to Jochen Hundsdoerfer and one anonymous referee of the American Accounting Association Annual Conference for helpful comments and advise. All remaining errors and deficiencies are our own.

- Contact author: Sebastian Eichfelder, Otto-von-Guericke-Universität Magdeburg, Fakultät für Wirtschaftswissenschaft, Universitätsplatz 2, 39106 Magdeburg, Germany, Tel.: +49-391-67-18811, Fax: +49-391-67-11142, Mail: sebastian.eichfelder@ovgu.de. 


\section{Introduction}

The question if and how taxes affect stock prices is a central aspect for firm valuation, tax planning and tax policy that has been frequently discussed (e.g. Blouin, Raedy, and Shackelford, 2002; Ayers, Lefanowicz, and Robinson, 2003; Dhaliwal, Li, and Trezevant, 2003). While the literature provides evidence that anticipated capital gains taxes will be reflected in the asset price (e.g. Günther and Willenborg, 1999; for a review see Hanlon and Heitzman, 2010), corresponding studies are generally based on the theory of market efficiency implying an immediate response of investors to new relevant information. Thus, the focus of the empirical literature is on announcement effects of tax law changes (Lang and Shackelford, 2000; Dai, Maydew, Shackelford, and Zhang, 2008; Blouin, Hail, and Yetman, 2009).

However, as research on tax salience suggests, tax effects on decision-making are not only driven by tax burdens and tax planning opportunities, but also by tax information and tax awareness of individual decision-makers (Chetty, Looney and Kroft, 2009; Finkelstein, 2009; Edgerton, 2012; Alstadsaeter and Jacob, 2013). Corresponding results suggest that private investors, even if they have heard about an upcoming tax reform, may not optimally consider taxes by reason of tax unawareness and procrastination behavior. Regarding the capitalization of taxes in asset prices, these findings raise some doubt about the optimal decision-making of private investors and the efficiency of financial markets in processing tax-relevant information.

Combining both strands of literature, we argue that the capitalization of capital gains taxes in asset prices does not only depend on tax rates and assessment bases, but also on the tax awareness of market participants and especially private investors with limited tax knowledge. Furthermore, as tax awareness cannot be regarded as constant over time, the capitalization of capital gains taxes (and likewise other forms of taxation) may not only be driven by announcement dates of upcoming tax reforms but also by the relevance of tax issues in the media affecting the degree of tax awareness in a society. Hence, it may be insufficient to focus exclusively on announcement dates of tax reforms to identify tax effects on asset pricing.

We refer to a recent major reform of German capital gains taxes in order to address these issues empirically. Before the reform, capital gains on private shareholdings were generally tax-exempt if the holding period exceeded one year. In May and in July 2007 the German federal parliament and the German federal council concluded a business tax reform including 
a capital gains tax with a flat rate of $26.38 \%$ (25\% income tax plus solidarity tax surcharge) on all private shareholdings acquired after December 31, 2008. Therefore, the reform generated a strong incentive for private investors to buy shares before its introduction date of the reform on January 1, 2009. Note that the taxation of well-informed institutional investors was not affected by this reform.

Assuming fully tax-aware investors and taking into account the long interval between the official announcement of the reform (July 2007) and its introduction (January 2009), market reactions should have been focused on the announcement date, while the corresponding introduction date should have been anticipated by the market. However, as documented by market research of Deutsche Bank (2008) and the largest German market research institute GfK (GfK, 2008; Hilmes, 2008) during the last months 2008, the majority of German private investors was either unaware or not fully aware about the capital gains tax reform.

In December 2008, the subject became a major issue of public debate and was strongly discussed by the media. Börse Online titled on December 18, 2008, "The count down for the capital gains tax is running" and on December 20 the Frankfurter Allgemeine Zeitung (as the probably most popular general daily newspaper for brokers) titled "Final spurt for tax savers". On December 22, Frank Wiebe wrote in Handelsblatt "There is a good reason to buy shares in the current year: the capital gains tax." Lange and Reiche from Manager Magazine Online warned investors by the end of the year 2008:,,There is little time to act. [...] The investor who wants to avoid the new capital gains tax has only four trading days left.[...]”. Then, on December 29, the Berliner Morgenpost concluded: "Private investors buy shares in order to avoid capital gains tax" (all statements translated from German language).

Therefore, we expect that private investors did not only focus on the announcement date of the German capital gains tax reform but also on its introduction date resulting in a strong impact on trading volumes and share prices by the end of 2008. There are two theoretical justifications for this hypothesis. First of all, the vivid public debate on the capital gains tax reform in December 2008 'alarmed' private investors resulting in higher tax awareness. Second, evidence from the psychological and financial literature suggests that private decision-makers tend to procrastinate savings and portfolio decisions up to the final possible decision moment (Akerlof, 1991; Ferrari and Dovidio, 2000; Ferrari and Hammer, 2002; Thaler and Bernartzi, 2004).

In our empirical analysis, we test for abnormal trading volumes, asset prices and daily returns of all stocks listed on the German stock market at the turn of the year 2008/2009. We do not 
consider announcement effects of the tax reform, which are hard to isolate and have already been investigated by Voeller and Müller (2011). ${ }^{1}$ Using difference-in-differences estimation, we find evidence for a temporarily strong increase in trading volumes and asset prices. Controlling for end-of-the-year effects, the average trading volume in the last two trading days 2008 exceeded the regular volume by $160 \%$. In addition, investors paid an asset price surcharge of about $7.4 \%$ in these days. On the contrary, we observe negative abnormal trading volumes and daily returns in the week following the turn-of-the-year 2008/2009. Thus, our research suggests shifting of share trades from 2009 to 2008 in order to avoid tax payments.

Our findings have important implications for tax policy and research. We are the first to argue and to show empirically that the capitalization of taxes in stock prices and trading volumes can be significantly affected by tax awareness. Thus, it may be insufficient to focus exclusively on announcement dates of tax reforms in order to identify the effect of tax law changes on asset pricing. If a significant fraction of investors will not be aware about the announcement date of a corresponding tax reform, such estimates may understate the true tax effect on asset pricing. In addition, tax policy might take use of such a behavior in order to avoid unwanted price and trading fluctuations.

Second, our paper highlights limitations of capital markets in processing tax-relevant information. As shown for the case of Germany, the announcement of a certain event may be ignored for a considerable time by a large fraction of market participants. Thus, unawareness and procrastination seem to be not only an issue for savings behavior and retirement annuities (Madrian and Shea, 2001; Carroll et al., 2009), but also for private shareholders. However, as the time to react expires, the awareness of the market increases, which may result in herd behavior and higher market volatility.

Third, our analysis points to opportunities for well-informed and tax-aware investors to generate tax arbitrage profits. If delayed market reactions close to introduction dates of tax reforms might be anticipated, an optimal strategy would be to sell shares exactly before the introduction date and to rebuy these shares about one week thereafter. Note that our regressions imply an unexpected average increase in share prices of about $7.4 \%$ in the last

\footnotetext{
Note that the capital gains tax reform 2009 was part of a broader reform package (German business tax reform 2008/2009). As these regulations were jointly announced and approved by the German legislator (see Section 2), an empirical identification of the isolated announcement of the German capital gains tax reform 2009 should be a hard task. However, that does not hold for the introduction date, as all other relevant reform measures of the business tax reform 2008/2009 were already introduced by January 2008 and not in January 2009 (like the capital gains tax reform).
} 
two trading days 2008, and that institutional investors were not affected by higher capital gains taxation. Thus, institutional investors might have benefited significantly from the reform.

The paper is organized as follows. Section 2 contains a brief overview of the German capital gains tax reform 2009 and the more comprehensive business tax reform 2008/2009. Section 3 develops theory and derives our hypotheses. Section 4 provides the identification strategy and the data. Section 5 reports and discusses our results. Section 6 concludes.

\section{The German capital gains tax reform 2009}

The introduction of the new German capital gains tax 2009 was embedded in the more general business tax reform 2008/2009. This reform introduced major changes in the German taxation of companies including the reduction of the corporate income tax rate from $26.38 \%$ to $15.83 \%$ (including solidarity tax surcharge), the broadening of the income tax base for businesses (e.g. by a revision of thin-capitalization tax rules and the abolishment of the deductibility of the German local business tax) and coordinated tax reforms for partnerships, single businesses and private persons. The main objective of the reform was to enhance Germany's attractiveness for national and international business investment. Relevant for our investigation is the revision of the tax system for capital earnings and capital gains of private persons. Note that the introduction date of capital gains and earnings taxation (January 2009) significantly differed from the introduction date of the other reform measures (January 2008). Therefore, corresponding tax effects may be isolated from the other regulations of the business tax reform 2008/2009.

First media reports on a major German reform of business taxation tax go back to April 10, 2006. In June 2006, a draft paper of the German ministry of finance reported about a general withholding tax on private capital earnings (including interests and dividends) and private capital gains with a flat rate. The established task force presented the integrated concept in November 2006. In January 2007, the decision was made to introduce the flat tax on private capital earnings and private capital gains on January 1, 2009 (in derogation from the introduction of the other reform measures on January 1, 2008). In addition, it was decided to maintain the old capital gains taxation for shares acquired before that date.

The final bill was presented in May 2007 and was approved shortly thereafter by the federal council and the federal parliament (May and July 2007). Figure 1 illustrates the described 
process of the German business tax reform 2008/2009 including the capital gains tax reform 2009 (for a more detailed review see Voeller and Müller, 2011):

[Figure 1 about here]

For shares bought before January 2009, the taxation of capital gains of German private investors depends on the holding period. If the holding period exceeds one year, investors may sell shares tax-free. Otherwise (holding period < one year), $50 \%$ of the capital gains were taxed with the regular progressive personal income tax rate (including solidarity tax surcharge) ranging from $0 \%$ to $47.48 \%$. Hence, the maximum effective capital gains tax rate on shares bought before January 2009 is $23.74 \%$.

By contrast, capital gains realized from shares bought after December 2008 are taxable with the minimum of the regular progressive income tax rate or a flat rate of $26.38 \%$ (including solidarity tax surcharge) on interests, dividends and capital gains. After 2008, there was no discriminative tax treatment depending on the length of the holding period. Table 1 illustrates the taxation before and after the capital gains tax reform 2009:

[Table 1 about here]

In general, investors face a considerably higher tax burden on capital gains if shares have been purchased after January 1, 2009. ${ }^{2}$ At a holding period longer than one year, the tax burden increases by $26.38 \%$ for taxpayers with a personal income tax rate of at least $25 \%$ (excluding solidarity tax surcharge). At a holding period smaller than one year, the additional tax burden increases inversely to the regular personal income tax rate. For example, at a personal tax rate of $26.38 \%$, the tax burden doubles from $13.19 \%$ for shares purchased before 2009 to $26.38 \%$ for shares purchased in 2009 and thereafter (including solidarity tax surcharge).

In spite of these clear tax incentives for private shareholders, a majority of Germans lacked awareness about the upcoming reform during the last months of 2008. A survey of the Deutsche Bank (2008) suggests that 100 days before the introduction date, $66 \%$ of German residents had some knowledge about the new capital gains tax, but only $11 \%$ considered the tax rate change in their trading decisions. Correspondingly, Guido Servais (the German marketing director for JP Morgan Asset Management) stated in September 2008 that only

2 That holds also for taxpayers with a regular personal income tax rate below $25 \%$. In these cases, the regular income tax rate applies after the capital gains tax reform 2009. By contrast, either $0 \%$ (holding period $\geq$ one year) or $50 \%$ (holding period < one year) of capital gains were taxed with the regular personal income tax rate before the capital gains tax reform 2009. 
$10 \%$ of private investors were planning to adjust their portfolio by reason of tax reform. ${ }^{3}$ According to a survey of GfK (2008) in November 3, 2008, only $30 \%$ of the respondents felt well-informed about the capital gains tax reform, while $30 \%$ obtained limited information and $40 \%$ were not informed at all. About two thirds claimed that they were planning to obtain better information until the end of the year 2008 .

Taking into account the limited knowledge of the German public, it should not be unexpected that the capital gains tax reform 2009 has been strongly discussed by the media in December 2008 (all statements translated from German language). Die Welt titled on December 3 "Final spurt to the capital gains tax", on December 7 "The last 25 days without a withholding tax on capital gains" and on December 9 "The stock market crisis as a benefit: Investors may use low share prices and save the new capital gains tax". RP Online emphasized at December 11, 2008 "The last chance to avoid the unpopular tax would be to buy stocks before the deadline on January 1, 2009." The Berliner Morgenpost encouraged private investors on December 14 "Attention capital gains tax! 15 Financial products for the final tax spurt 2008" and the Frankfurter Rundschau even warned on December 15: "The final spurt might end up in exaggerated share prices".

As mentioned previously, Frankfurter Allgemeine Zeitung on December 20 announced the "Final spurt for tax savers". Handelsblatt titled on December 22 "Last call! Who wants to buy shares in this year must hurry up - Higher taxes on January”. Herrmann from TAZ online pointed out on the morning of December 29: "Exactly two days are left for investors to stock up on shares on the capital markets, for which a tax-free selling is possible after one year of holding." Even the Tagesschau (as the most important daily news on German television) reported on December 30 on the capital gains tax reform $2009 .{ }^{4}$ As result, average awareness of German private investors regarding the introduction of the new capital gains tax should have increased significantly by the end of 2008 .

\section{Theory and hypotheses}

Corresponding to Lang and Shackelford (2000), the current share price $P_{0}$ of an asset can be modelled as a function of constant free cash flows $F$, the shareholder distribution of the

\footnotetext{
http://www.dasinvestment.com/nc/berater/news/datum/2008/09/04/ex-linde-partners-strategie-steht-imfondsnamen/ (online access June 24, 2013).

4 See for online access http://www.tagesschau.de/archiv/sendungsarchiv100 _date-20081230.html.
} 
following period (with a constant growth rate in future periods) $D_{1}$, the dividend tax rate $\tau^{d}$, the capital gains tax rate $\tau^{c}$ and the discount rate $r^{5}$

$$
P_{0}=\frac{D_{1} \cdot\left(1-\tau^{d}\right)}{r \cdot\left[\tau^{c}+\frac{D_{1}}{F} \cdot\left(1-\tau^{c}\right)\right]} .
$$

While this model is based on the assumption of market efficiency, it does not account for behavioural aspects like the degree of tax awareness. Gamage and Shanske (2011) define the concept of tax awareness as “(...) any systematic differences between how taxpayers would perceive the costs of taxation in a hypothetical world of perfect economic rationality consistent with neoclassical economics and how taxpayers actually perceive the costs of taxation in the real world." Reasons for tax unawareness are informational transaction costs, the complexity and changeability of tax regulations and the bounded rationality of private investors. Empirical findings show that drawing the attention of individuals to a certain tax increases their tax awareness, hence their responsiveness to this tax (Chetty, Looney, and Kroft, 2009; Finkelstein, 2009). Amending the model by taw awareness variables $\theta^{c}$ and $\theta^{d}$ for capital gains taxes and dividend taxes results in

$$
P_{0}=\frac{D_{1} \cdot\left(1-\tau^{d} \cdot \theta^{d}\right)}{r \cdot\left[\tau^{c} \cdot \theta^{c}+\frac{D_{1}}{F} \cdot\left(1-\tau^{c} \cdot \theta^{c}\right)\right]} .
$$

In this model, $\theta^{c}$ and $\theta^{d}$ can take values between zero (investor is tax-unaware) and one (investor is fully tax-aware). Following Lang and Shackelford (2000), the marginal effect of capital gains taxes on share prices can then be described by

$$
\frac{\partial P_{0}}{\partial \tau^{c}}=-P_{0} \cdot \theta^{c} \cdot \frac{F-D_{1}}{\tau^{c} \cdot \theta^{c} \cdot\left(F-D_{1}\right)+D_{1}} .
$$

In general, free cash flows $F$ are higher than dividends $\mathrm{D}_{1}$, and shareholders realize positive capital gains. Thus, the derivative (3) is negative, and higher expected capital gains taxes reduce the share price. However, that holds only for tax-aware investors. If $\theta^{c}$ approaches zero, we generally obtain

\footnotetext{
5 Note that the simplifying assumption of constant payments, constant interest rates and constant tax rates can be justified by imperfect foresight of the market participants taking current values as expectations for future values. Similar implications of the modelling would follow if free cash flows were assumed to grow over time (Lang and Shackelford, 2000).
} 


$$
\lim _{\delta \theta^{c} \rightarrow 0} \frac{\partial P_{0}}{\partial \tau^{c}}=0
$$

Hence, investors who entirely lack tax awareness will expectedly not react to capital gains taxation. Note that $\theta^{c}$ of an individual investor may change suddenly over time. For example, a private investor who has heard about an upcoming tax reform without knowing any detail, would be informed by relatives, friends or his tax accountant and would be strongly advised to care about these issues immediately.

Similar to Dai et al. (2008), our argument may be extended to a market equilibrium framework. We focus on demand-sided capitalization effects as lock-in effects are not relevant in our empirical setting. ${ }^{6}$ Therefore, we take the reservation price of the sellers as fixed and conclude that the supply curve will not be affected by the German capital gains tax reform 2009.

By contrast, interpreting formula (2) as a representation of the equilibrium price from a buyer perspective, it turns out quite clearly that higher capital gains taxation will shift the demand curve and reduce average demand. However, this well-known effect of capital gains taxation will be mediated in our model by the average level of tax awareness in the market. If the number of tax-aware investors is high, capital gains taxes will be capitalized in the equilibrium price as described by Shackelford and Verrechia (2002) and Dai et al. (2008).

However, if most market participants are tax-unaware, information on capital gains taxation would be initially ignored implying a small impact on the demand curve as well as on trading volumes and equilibrium prices. In such a setting, financial markets might show a delayed reaction on tax reforms resulting from a steadily dissemination of tax information. ${ }^{7}$ In case of a strong increase in tax awareness, there might also be an immediate market reaction resulting in significant effects on trading behavior.

An important implication of our argument is that tax-aware investors may use their superior information to increase their trading profits. This can be exemplified by two private investors $\mathrm{A}$ and $\mathrm{B}$ with different tax awareness levels $\left(\theta_{A}^{c}=1 ; \theta_{B}^{c}=0\right)$ in view of an upcoming increase in the capital gains tax rate. We assume further that B will adjust his or her awareness to 1

6 The lock-in effect is valid if the seller will demand for a higher selling price in order to compensate for unexpectedly high capital gains taxes. However, in our setting capital gains taxes were only increased for shares purchased by private investors after January 1, 2009. Therefore, sellers of shares in the relevant period (December 2008) were not affected by unexpectedly high capital gains taxes.

7 This argument fits well with empirical evidence provided by Hirshleifer, Lim and Teoh (2009) for delayed market reactions to earnings news. 
after the increase of the tax rate (at the latest when capital gains are realized and capital gains taxes will have to be paid). As information on the tax law change becomes available, the reservation price of A $P_{A}$ decreases, while $P_{B}$ remains constant. Thus, A could sell shares to B obtaining for the price $P_{B}$, while B would realize the loss resulting from the higher capital gains tax in future.

Regarding the German capital gains tax reform 2009, we have good reason to believe that the majority of the affected private investors (institutional investors were unaffected) was far from being fully tax-aware. This is underlined by Deutsche Bank (2008) as well as by market research of the GfK for the Dresdner Bank and JP Morgan Asset Management (GfK, 2008; Hilmes, 2008). In addition, there are two arguments for a strong increase in average awareness regarding the capital gains tax reform 2009 in late December 2008.

First of all, as mentioned before in Section 1 and Section 2, there was a vivid public discourse on the capital gains tax reform 2009 in December 2008 in major online portals (e.g. www.dasinvestment.com, Börse Online, Taz online, Manager Magazin Online) and daily newspapers (e.g. Berliner Morgenpost, Die Welt, Frankfurter Allgemeine Zeitung, Frankfurter Rundschau, Handelsblatt) increasing the awareness of the German public regarding that issue.

Second, as documented by economic and psychological research, individuals tend to procrastinate actions (Akerlof, 1991; Hammer and Ferrari, 2002), which is especially an issue for savings behavior (see Thaler and Bernartzi, 2004; Carroll et al., 2009, with further references). Ferrari and Dovidio (2000) find evidence that “(...) people higher in decisional procrastination are systematic and strategic but search for more information specifically about chosen alternatives." This fits well with our story as the acquisition of shares is a risky task and media discussion in December 2008 provided more information on the capital gains tax reform 2009. In addition, experiments from Ariely and Wertenbroch (2002) suggest that selfimposed deadlines of individuals are not as effective as externally-imposed deadlines to overcome procrastination. Hence, the introduction date of the reform (as the final deadline) provided a strong incentive for procrastinators and initially unaware investors.

Regarding the German capital gains tax reform 2009, a rational strategy in order to avoid capital gains taxes was the acquisition of shares before January 1, 2009. Note that shares acquired before that date were not affected by the flat tax on capital gains (even in future periods). While market reactions of well-informed rational taxpayers should have been focused on the announcement dates of the reform (see also Voeller and Müller, 2011), we 
further expect a delayed market reaction close to the introduction date resulting from a lack of tax awareness and procrastination of investment behavior. Hence, we hypothesize:

HYPOTHESIS 1a: Trading volumes were abnormally high in the time closely before the introduction of the German capital gains tax reform 2009.

An increased demand for shares implies higher asset prices if it is not related to a corresponding increase in share supply. In addition, the capital gains tax reform 2009 should also have increased the willingness to pay for "tax-free" shares if these shares were compared to taxable shares bought in 2009. Therefore, we expect an abnormal increase in asset prices by the end of 2008 as well.

HYPOTHESIS 1b: Daily returns were abnormally high in the time closely before the introduction of the German capital gains tax reform 2009.

HYPOTHESIS 1c: Asset prices were abnormally high in the time closely before the introduction of the German capital gains tax reform 2009.

While the introduction of capital gains taxes in Germany resulted in a short-run increase in the demand for shares by the end of 2008, we expect a reversal effect at the beginning of 2009 . The main argument for this hypothesis is a demand-sided bring-forward effect. As the capital gains tax reform increased the relative attractiveness of shares bought in 2008, we expect a shifting of trades from 2008 to 2009. In addition, the introduction of the capital gains taxes rather reduced the attractiveness of share trades by 2009. Therefore, we conclude:

HYPOTHESIS 2a: Trading volumes were abnormally low in the time closely after the introduction of the German capital gains tax reform 2009.

After the introduction of the new capital gains tax in January, 2009, economic theory implies a decreasing demand for shares as well as a decreasing willingness of private investors to pay for shares. Therefore, we expect abnormally low returns up to the point that stock prices reached their regular 'normal' level. This consideration suggests abnormally high asset prices and significantly negative abnormal returns in the period shortly after the introduction date of the capital gains tax reform 2009.

HYPOTHESIS 2b: Daily returns were abnormally low in the time closely after the introduction of the German capital gains tax reform 2009.

HYPOTHESIS 2c: Asset prices were abnormally high in the time closely after the introduction of the German capital gains tax reform 2009. 
While media reports on capital gains taxation in December 2008 increased average tax awareness by German private investors, an additional incentive for procrastination resulted from Christmas celebrations 2008 including preparation activities like the invitation of friends and family members or the purchase of presents. In Germany, Christmas is celebrated from December 24 to December 26. On these days as well as on weekends and the New Year's Eve, the German financial market is closed. In the year 2008, December 24 was a Wednesday. As a result, there were only two trading days left between Christmas 2008 and New Year's Eve (December 29 and December 30). As result, we expect that market reactions resulting from the capital gains tax reform 2009 were especially strong on these two days.

HYPOTHESIS 3a: Trading volumes were especially high in the two days before the introduction of the German capital gains tax reform 2009.

HYPOTHESIS 3b: Daily returns were especially high in the two days before the introduction of the German capital gains tax reform 2009.

HYPOTHESIS 3c: Asset prices were especially high in the two days before the introduction of the German capital gains tax reform 2009.

\section{Identification strategy and data}

\subsection{Identification strategy}

A major strategy of the existing literature to identify pricing effects of capital gains taxes relies on a hypothesized differential impact of capital gains taxes on dividend-paying firms and non-dividend paying firms (Amoako-Adu, Rashid, and Stebbins, 1992; Lang and Shackelford, 2000; Dai, Maydew, Shackelford, and Zhang, 2008). This approach is based on the fact that returns from non-dividend-paying firms are exclusively based on capital gains, while returns from dividend-paying firms also result from dividends. Therefore, if investors capitalize taxes in a rational way, capital gains taxes will have a stronger impact on nondividend-paying firms compared to dividend-paying firms.

An important assumption of this approach is that assets are priced rationally by investors being well-informed about all relevant tax issues. For that reason, this identification strategy does not seem to be feasible for our analysis of "tax-unaware" German investors, because these investors will typically not only be unaware of capital gains taxes as such but also of their differential effects on the returns of dividend-paying and non-dividend-paying firms. Taking into account the complexity of the correlation between asset prices, capital gains taxes 
and dividends, this argument holds even in case of a temporary increase of tax awareness by the end of $2008 .^{8}$

As a result, we use an alternative identification strategy relying on comparisons between treated assets and non-treated assets. We interpret the introduction of a flat tax on private capital gains in Germany in January 2009 as a natural experiment, which can be analyzed by difference-in-differences estimation. Considering the well-known home bias of private investors (French and Poterba, 1991; Ahearne, Griever, and Warnock, 2004; Van Nieuwerburgh and Veldkamp, 2009), we expect that tax changes in Germany will have a stronger impact on assets of the German stock market compared to assets of other major European stock markets. Jochem and Volz (2011) show that German investors hold slightly more than $50 \%$ of their total shares on the German stock market. In case of private investors this share should be even higher. Thus, trading activities due to the capital gains tax reform 2009 should have the greatest impact on the German stock market. For that reason, asset prices from other major European stock markets can be considered as an appropriate control group for shares traded on the German stock market.

A potential problem of such an approach might be that the end-of-the-year effect (Starks, Yong, and Zheng, 2006) of the German stock market is structurally different from other European stock markets. To control for structural differences in the end-of-the-year effects between the German stock market (treatment group) and other major European stock markets (control group), we do not only consider observations from the turn-of-the-year 2008/2009, but also observations of preceding and following years. In detail, we consider observations of asset prices and trading volumes of 30 trading days before and 30 trading days after the-turnof-the-year 2008/2009 (treatment period) as well as corresponding trading data for the years 2007/2008 and 2009/2010 (control period).

Using control groups as well as control periods, our estimation strategy may also be denoted as difference-in-differences-in-differences estimation. This approach has a number of advantages. By considering control groups from other European countries, we are able to account for general market trends varying over time. By including control periods, we control for Germany-specific effects that do not vary significantly over time. In addition, we include a comprehensive set of control variables, namely stock fixed effects, stock market-year fixed

\footnotetext{
A careful analysis of the German practitioner literature of that period does not reveal any evidence that private investors were advised to buy "non-dividend-paying firms" to react on the capital gains tax reform 2009.
} 
effects, industry-year fixed effects and major structural variables (EBITDA, market value, book value).

Taking into account that the German stock exchange ${ }^{9}$ is one of the biggest stock exchanges in Europe, we select Western European major stock exchanges as control group, namely United Kingdom (London Stock Exchange) and France (Paris Stock exchange as part of NYSE Euronext). This can be justified by the following aspects. 1) London Stock Exchange and Paris Stock Exchange are geographically close to the German trade center Frankfurt. 2) France and the United Kingdom are culturally and politically closely related to Germany, e.g. they are member states of the European Union. 3) United Kingdom, France and Germany are similar countries in terms of population size, geographic area, economic development and growth. 4) London Stock Exchange can be interpreted as a leading trading place affecting strongly other European stock markets. 5) There were no major tax reforms implemented in the United Kingdom or France during the treatment or control period which could bias our results.

\subsection{Data}

As data base, we rely on stock market and financial statement information using the DATASTREAM database. While information on asset prices and trading volumes for each stock is available for each trading day, financial statement data is based on business annual reports. As we use data of 60 trading days for each period, stock and stock market, we are provided with 261,900 stock-day observations. ${ }^{10}$ We consider information on all officially listed companies in Germany, France and the UK.

This raw data has been adjusted in two ways. First of all, we exclude all observations with missing information on asset prices, trading volumes or control variables. Second, we do not consider observations with negative earnings before interests, taxes, depreciations and amortizations (EBITDA) ${ }^{11}$ or a negative price-to-book value (PTBV). Therefore, our final data is an unbalanced panel with 179,587 stock-day observations from five years: 52,317 observations from the German stock exchange, 68,473 observations of the Paris Euronext stock exchange and 58,797 observations of the London stock exchange.

\footnotetext{
9 The main stock exchange in Germany is Frankfurt stock exchange. However, we also consider data from firms listed at other German stock exchanges like Munich or Stuttgart.

10 While stock markets in Germany are closed on Christmas and the New Year's Eve, trading on these days is typically possible in France and the UK. To align our data, we do not consider these trading days from France and the UK. Note that this effect is not only relevant for the year 2008/2009, but also for the preceding and the following observation periods. Thus, it should not bias our regression results.

11 We exclude these observations as a logarithmic specification is not possible for a negative EBITDA.
} 
Descriptive statistics on our major variables of interest (asset price, daily return, trading volume) and our most relevant control variables (market value, book value, EBITDA) are provided by Table 2 . The daily return is measured as the relative change of the actual asset price compared to the last years' asset price in percentage points. The trading volume is the number of trades of a given share per day. The book value has been calculated as the asset price divided by the price-to-book-ratio und multiplied with the number of shares. EBITDA are the current year earnings before interests, taxes, depreciations and amortizations. Asset price, market value, book value and EBITDA are reported in local currency ( $€$ in Germany and France and British pounds in the UK).

[Table 2 about here]

Table 2 reveals that the average stock of the German market has a somewhat smaller market value and book value compared to France and the UK. In addition, average asset prices per stock are lower. The mean daily returns in all three stock markets are very small and statistically not different from zero. The average number of trades per day (trading volume) is higher in the UK and somewhat smaller in France, while average EBITDA is very similar in all three markets. In order to account for differences between stock markets, we consider stock fixed effects as well as stock market-year fixed effects in our regression analysis.

\section{Empirical results}

\subsection{Graphical analysis}

For our graphical analysis, we derive estimates for abnormal asset prices, abnormal returns and abnormal trading volumes using the following regression model:

$Y_{i t}=\alpha+\gamma \cdot C_{i t}+\vartheta_{i t}+\psi_{i t}+v_{i}+u_{i t}$

As dependent variables $Y_{i t}$, we use the logarithm of trading volume (measured by 1,000 trades per day), the logarithm of the asset price in local currency ( $€$ or British pound) and the relative change of asset prices for each trading day (daily return). Regarding trading volume and asset price, we choose a logarithmic specification to obtain a relative measure for trading and pricing effects and to ensure the linearity in variables.

Our vector of controls $C_{i t}$ accounts for the logarithm of market value, the logarithm of book value and the logarithm of EBITDA (all measured in millions of local currency). Regarding the market value, we do not account for changes within a given observation period (30 trading days before and after the end of a given year). Thus, we exclusively use the corresponding value of the first observation for each period. This is to avoid endogeneity, as the market 
value might be driven by the asset price and not vice versa. We use realized EBITDA of the following period (e.g. EBITDA 2009 for the turn-of-the-year 2008/2009) as a proxy for the expected development of profits of listed companies. Table 3 provides descriptive statistics of our dependent and exogenous variables.

[Table 3 about here]

We also consider stock market-year fixed effects (set of dummy variables for each stock market-year combination) $\vartheta_{i t}$ and industry-year fixed effects (set of dummy variables for each industry-year combination) $\psi_{i t}$ to account for trends and exogenous shocks. In addition, we consider the panel nature of our data by including stock fixed effects $v_{i}$. In doing so, we also control for local currency effects. Therefore, our analysis is exclusively driven by variation in variables over time. In this model, abnormal daily returns, asset prices and trading volumes for each stock-day observation are measured by the regression residual $u_{i t}$.

In Figure 2 to Figure 4, we report average residuals for the treatment group with the introduction of the capital gains tax (Germany) and the control group (France and UK) for the 30 trading days before and after the end-of-year 2008/2009. All figures reveal that the regression residuals of the treatment group and the control group are closely correlated over the whole observation period. That holds especially for asset prices and daily returns. Therefore, our control group should provide us with an appropriate reference point to identify the impact of the German capital gains tax reform 2009.

[Figure 2 about here]

At the beginning of the observation period, abnormal trading volumes in Figure 2 are almost identical in the treatment group and the control group. However, we find a strong deviation of trading volumes beginning about one week before the turn-of-the-year 2008/2009. In this week there is an almost exponential increase in German abnormal trading volumes with a maximum difference compared to France and the UK by the last trading day in 2008. Thereafter, we find a strong decline in German abnormal trading volumes. Furthermore, abnormal trading volumes are constantly higher in the control group in 2009. Overall, our evidence fits well with the interpretation that German investors increased their trades by the end of 2008 and have shifted trades from 2009 to 2008 in order to avoid the German capital gains tax.

[Figure 3 about here] 
Regarding abnormal daily returns (Figure 3), we do not find significant deviations between treatment group and control group apart from the week before and the week after the introduction of the German flat tax on capital gains. In line with our expectations, abnormal returns of the treatment group are higher before and lower after the introduction of the capital gains tax. Therefore, the introduction of the German capital gains should have resulted in a temporary increase in the demand for shares as well as in a temporary increase in asset prices. This interpretation is confirmed by our evidence on abnormal asset prices surrounding the turn-of-the-year 2008/2009.

[Figure 4 about here]

As shown by Figure 4, abnormal asset prices in the treatment groups are almost identical to the control group apart from about one week before and one week after the turn-of-the-year 2008/2009. All-in-all our graphical analysis clearly confirms our theoretical considerations and hypotheses.

\subsection{Regression analysis}

As reported by subsection 4.1., we interpret stock-day observations of the German stock market at the end-of-the-year 2008/2009 as treatment group and corresponding observations in France and the UK as control group to identify the impact of the German capital gains tax reform on trading volumes, asset prices and daily returns by difference-in-differences estimation. In addition, we use observations in corresponding reference periods in 2006/2007, 2007/2008, 2009/2010 and 2010/2011 to control for structural differences in stock markets and end-of-the-year effects. Furthermore, we account for the same control variables as in our graphical analysis in section 5.1. This results in the following regression model with the dependent variables $Y_{i t}$ logarithm of trading volume, logarithm of asset price and daily return in percentage points:

$$
\begin{aligned}
Y_{i t}= & \alpha+\beta_{1} \cdot \text { Before }+\beta_{2} \cdot \text { Before Germany }+\beta_{3} \cdot \text { Before } 0809+\beta_{4} \cdot \text { Before DiD } \\
& +\gamma_{1} \cdot \text { After }+\gamma_{2} \cdot \text { After Germany }+\gamma_{3} \cdot \text { After } 0809+\gamma_{4} \cdot \text { After DiD } \\
& +\delta \cdot C_{i t}+\vartheta_{i t}+\psi_{i t}+v_{i}+u_{i t}
\end{aligned}
$$

In this model, Before is a dummy variable with a value of one in a certain time window before the turn-of-the-year (otherwise zero). In line with our graphical evidence, we choose one week as standard reference period. This implies that the main effect of the German capital gains tax on trading volumes and asset prices can be observed one week (five trading days) before its introduction by the turn-of-the-year 2008/2009. However, we also test alternative reference periods (two days corresponding to our hypotheses $3 \mathrm{a}$ to $3 \mathrm{c}$ and two weeks). 
Before Germany and Before 0809 are time dummies controlling for structural differences of end-of-the-year-effects in the German stock exchange or in the year 2008/2009. They are calculated as an interaction term of Before and a dummy variable for Germany (respectively for the year 2008/2009). The effect of the German capital gains tax reform is captured by Before DiD, which is an interaction term of Before, a dummy variable for Germany and the year dummy for $2008 / 2009$. In line with our hypotheses, we expect that Before DiD is positively correlated to asset prices, daily returns and trading volumes.

Similar to Before, After is a dummy variable with a value of one in a certain reference period after the turn of a given year. After Germany, After 0809 and After DiD are calculated in the same way as the corresponding interaction terms of our Before dummy. Corresponding to our hypotheses, we expect a positive correlation of After DiD with the asset price and a negative correlation of After DiD with daily returns and trading volumes.

The control variables conform to our regression model (6). We estimate a simplified model including a limited set of controls (stock market-year fixed effects and stock fixed effects) and an extended model further including industry-year fixed effects as well as Market value, Book value and EBITDA (all measured by the logarithm of the corresponding values in millions of local currency). The estimation has been executed by OLS. We use robust standard errors being clustered for each share to account for heteroscedasticity and the correlation of standard errors over time.

The regression results for the standard reference period of one week (five trading days) are reported by Table 4 . In the models for daily returns, the regression coefficients of the dummy can be interpreted as a change in the daily return in percentage points. In the logarithmic models for asset prices or trading volumes, our results are to be interpreted as semielasticities. Note that in this case the estimated dummy variable coefficients have to be recalculated in order to obtain the relative effect on the dependent variable. As shown by Kennedy (1981), the relative change can be approximated by $\exp \left(\hat{\beta}_{i}-1 / 2 \cdot \operatorname{Var}\left(\hat{\beta}_{i}\right)\right)-1$, with the estimated regression coefficient $\hat{\beta}_{i}$ and the variance $\operatorname{Var}\left(\hat{\beta}_{i}\right)$.

[Table 4 about here]

The regression results for our primary variables of interest (Before DiD and After DiD) confirm our theoretical expectations. For our interpretation we focus on the extended models with a higher number of control variables. Confirming Hypothesis 1a and Hypothesis 2a, the average daily trading volume of the German stock market in 2008/2009 was unexectedly 
about $122 \%$ higher before the introduction of the tax (Before DiD) and about $11 \%$ lower thereafter (After DiD). Hence, trading volume seems to have been shifted up-front from January 2009 to December 2008. Regarding asset price, we find an about $3.2 \%$ to $3.3 \%$ higher price level one week before and one week after the introduction date, which confirms the hypotheses $1 \mathrm{~b}$ and $2 \mathrm{~b}$. In line with the hypotheses $1 \mathrm{c}$ and $2 \mathrm{c}$, we find on average an about 2.1 percentage points higher (1.3 percentage points lower) abnormal daily return before (after) the introduction of the tax. Addressing the hypotheses $3 \mathrm{a}$ to $3 \mathrm{c}$, we estimate regressions with an alternative reference period of two trading days before and after the turn-of-the-year. The results are reported by Table 5 .

[Table 5 about here]

The results confirm our expectations. For the extended models with the higher number of control variables, we find an about $6.3 \%$ higher average price level before the introduction date and a still $4.7 \%$ higher price level thereafter. The abnormal daily return is 2.1 percentage points before the turn-of-the-year 2008/2009 and minus 1.7 percentage points after the tax reform. The trading volume in the two last German trading days in 2008 was about $151 \%$ higher than the "normal" volume (Before DiD). However and contrasting our expectations, we do not find a significant decrease in the trading volume in the two days after the introduction date. Thus, the pull-forward effect of the capital gains tax rather affected trades at the end of the first trading week 2009.

While Table 5 shows an especially strong increase of the price level and the trading volume within the last days in 2008, it cannot be taken as evidence that corresponding estimates are statistically different from the estimates in Table 4. Therefore, we re-estimate the model including all variables from both regressions. Results are provided by Table 6 .

[Table 6 about here]

As documented by our results on Before DiD and After DiD for two days (2D) as well as Before DiD and After DiD for one trading week (1W), we find evidence that higher trading volumes and price levels were especially focused on the last trading days between Christmas and New Year's Eve 2008. However, we do not find a significant difference for daily returns. For the two days after the turn-of-the-year 2008/2009 we obtain higher abnormal asset prices and lower daily returns. By contrast, combining our estimates for After DiD (2D) and After $\operatorname{DiD}(1 \mathrm{~W})$, there is only a significantly lower trading volume in the last three trading days of the first trading week in January 2009. Thus, trading volume seems to have needed some time to drop from an abnormally high level to an abnormally low level. 
The results of Table 6 clearly confirm our expectations and hypotheses. They also provide us with a more detailed estimate on market reactions due to the capital gains tax reform 2008/2009. Combining the estimates on all relevant variables and focusing on the models with a higher number of controls, the abnormal increase in asset prices (trading volumes) was $2.0 \%(104 \%)$ in the first three days of the last week 2008 and $7.4 \%(160 \%)$ in the last two trading days in 2008. The maximum increase in the price level can be calculated by the abnormal daily returns of about 2 percentage points in the last week. Therefore, prices increased on average by $10.3 \%$ during the last week.

\subsection{Cross checks}

We calculated a number of cross checks to control for the robustness of our regression results. First of all, we controlled for alternative identification periods of market reactions (e.g. two weeks). In line with our graphical evidence, we did not find strong market reactions for the second last week of the year. Second, we increased the length of our observation period (identification period plus control period) for our investigation to 60 trading days before and after the turn-of-each year 2008/2009 (altogether 120 trading days). Corresponding results do not differ significantly from our basic analysis. Third, we increased the number of control periods from two (2007/2008 and 2009/2010) to four (2006/2007, 2007/2008, 2009/2010, 2010/2011) in order to find out if our results are driven by events of our reference periods. Again, results correspond to our basic analysis.

Fourth, we made additional regressions including observations with negative EBITDA. The consideration of these observations does not affect our estimates. Fifth, we amended our data by additional observations from the Spanish stock market (Madrid stock exchange) to account for the robustness of our control group. Corresponding results are in line with our main approach. Furthermore, we also made regressions considering only one major European capital market as control group (either Paris Euronext Stock Exchange or London Stock Exchange or Madrid Stock Exchange). These regressions do also confirm our basic analysis.

\section{Conclusion}

In this paper we address the question, if and how tax awareness and procrastination behavior may affect the impact of capital gains taxation on trading volumes and asset prices. We extend existing theoretical research on asset pricing by evidence on tax awareness and procrastination and hypothesize that not only the announcement date of a new tax will affect 
trading volume and asset pricing, but also its introduction date if this is related to tax awareness.

To address these issues empirically, we analyze the German introduction of a general flat tax of $26.38 \%$ on capital gains of private investors in January 2009. Our research suggests that an increased level of tax awareness - driven by media reports on the introduction of the flat capital gains tax in 2009 - and procrastination behavior resulted in a strong increase in asset prices and trading volumes by the introduction date of the new tax. Therefore, investors seem to have paid an average surcharge of about $7.4 \%$ during the last trading days of 2008 , while prices increased unexpectedly by about $10.3 \%$ during the last week. In line with our interpretation, we find that abnormal daily returns and trading volumes were significantly higher before the introduction date of the new German capital gains tax and significantly lower thereafter. This short-term effect was more pronounced for time periods close to the introduction date of the tax and vanished in the long run.

Taking into account the existing literature on asset pricing, our research has a number of interesting implications. First of all, we argue and find evidence that tax policies not necessarily affect all types of investors. Thus, if investors only have a limited tax knowledge and high transaction costs to gain more detailed information, their reaction on tax policies might be limited or delayed. As a result, policy makers might use information policy to affect investor behavior and to reduce undesirable tax effects.

Second, our findings provide evidence that stock markets are not necessarily efficient in processing tax information. If there is a relevant number of investors being unaware about a certain event (e.g. the German capital gains tax reform 2009), this information might be ignored for a considerable period up to a moment where investor awareness increases. Thus, an important implication of our paper is the relevance of investor awareness and procrastination effects, which might result in herd behavior and higher market volatility in case of a strong increase of public awareness.

Third, our findings can be interpreted as evidence for potential tax arbitrage strategies of banks, insurances and other well-informed investor types. As suggested by our regression results, investors paid an average price surcharge of about $7.4 \%$ during the two days before the introduction date of the capital gains tax reform 2009. Therefore, anticipating such market reactions, it would have been a good strategy for well-informed investors to buy shares, sell them shortly before the introduction date and to rebuy them again after the turn-of-the-year 2008/2009. Note that the German capital gains tax reform 2009 was only relevant for private 
investors and not for institutional investors like corporations. Thereby, higher capital gains taxes on shares bought in 2009 were only a burden for private investors, but not for institutional investors. From this perspective, the capital gains tax reform 2009 should have been a welcome possibility of well-informed investors to generate higher trading profits. 


\section{References}

Ahearne, A., Griever, W., Warnock, F., 2004. Information costs and home bias: An analysis of U.S. holding of foreign equities. Journal of International Economics 62, 313-336.

Akerlof, G.A., 1991. Procrastination and obedience. The American Economic Review 81 - Papers and Proceedings of the $103^{\text {rd }}$ Annual Meeting of the American Economic Association, 1-19.

Andersen, A., Nielson, K.M., 2011. Participation constraints in the stock market: Evidence from unexpected inheritence due to sudden death. Review of Financial Studies 24, 1667-1697.

Alstadsaeter, A., Jacob, M., 2013. The effect of awareness and incentives on tax evasion. CESifo Working Paper No. 4369.

Amoako-Adu, B., Rashid, M., Stebbins, M., 1992. Capital gains tax and equity values: Empirical test on stock price reaction to the introduction and reduction of capital gains tax exemption. Journal of Banking and Finance 16, 275-287.

Ariely, D., Wertenbroch, K., 2002. Procrastination, deadlines, and performance: Self-control by precommitment. Psychological Science 13, 219-224.

Ayers, B., Lefanowicz, C., Robinson, J., 2003. Shareholder taxes in acquisition premiums: The effect of capital gains taxation. The Journal of Finance 58, 2785-2803.

Ayers, B., Li, O.Z., Robinson, J.R., 2008. Tax-Induced trading around the Taxpayer Relief Act of 1997. Journal of the American Taxation Association 30, 77-100.

Blouin, J.L., Hail, L., Yetman, M.H., 2009. Capital gains taxes, pricing spreads, and arbitrage: Evidence from cross-listed firms in the U.S.. The Accounting Review 84, 1321-1361.

Blouin, J.L., Raedy, J.S., Shackelford, D.A., 2002. Equity price pressure from the 1998 reduction in the capital gains holding period. Journal of the American Taxation Association 24 (Supplement), 70-93.

Carroll, G.D., Choi, J.J., Laibson, D., Madrian, B.C., Matrick. A., 2009. Optimal defaults and active decisions. Quarterly Journal of Economics 124, 1639-1674.

Chetty, R., Looney, A., Kroft, K., 2009. Salience and taxation: Theory and evidence. The American Economic Review 99, 1145-1177.

Dai, Z., Maydew, E., Shackelford, D., Zhang, H., 2008. Capital gains taxes and asset prices: Capitalization or lock-in? The Journal of Finance 63, 709-742.

Dhaliwal, D., Li, O.Z., Trezevant, R., 2003. Is a dividend tax penalty incorporated into the return on a firm's common stock? Journal of Accounting and Economics 35, 155-178.

Deutsche Bank, 2008. Deutsche Bank Umfrage: 100 Tage bis zur Abgeltungsteuer, Presse-Information vom 19. September 2008, Deutsche Bank: Frankfurt am Main, https://www.deutsche-bank.de/presse/de/content/presse_informationen_2008_4073.htm

Edgerton, J., 2012. Investment, accounting, and the salience of the corporate income tax. NBER Working Paper No. 18472.

Ferrari, J.R., Dovidio, J.F., 2000. Examining behaviourial processes in indecision: Decisional procrastination and decision-making style. Journal of Research in Personality 34, 127-137.

Finkelstein, A., 2009. E-Z TAX: Tax salience and tax rates. The Quarterly Journal of Economics 124, 969-1010.

French, K., Poterba, J., 1991. International diversification and international equity markets. The American Economic Review 81, 222-226.

Gamage, D., Shanske, D., 2011. The case for reducing the market salience of taxation. National Tax Association, Proceedings of the $103^{\text {rd }}$ Annual Conference 2010, 48-53. 
GfK, 2008. Abgeltungsteuer: Eine Untersuchung der GfK Marktforschung. GfK: Nürnberg.

Günther, D.A., Willenborg, M., 1999. Capital gains tax rates and the cost of capital for small business: Evidence from the IPO market. Journal of Financial Economics 53, 385-408.

Hammer, C.A., Ferrari, J.R., 2002. Differential incidence of procrastination between blue- and whithcollar workers. Current Psychology 24, 333-338.

Hanlon, M., Heitzman, S., 2010. A review of tax research. Journal of Accounting and Economics $50,127-178$.

Hilmes, C., 2008. Abgeltungsteuer jedem Fünften unbekannt, http://www.dasinvestment.com/nc/berater/news/datum/2008/09/04/ex-linde-partners-strategiesteht-im-fondsnamen/online access June 24, 2014).

Hirshleifer, D., Lim, S.S., Teoh, S.H., 2009. Driven to distraction: Extraneous events and underreaction to earnings news. Journal of Finance 63, 2287-2323.

Jochem, A., Volz, U., 2011. Portfolio holdings in the Euro area: Home bias and the role of international, domestic and sector-specific factors. Economic Discussion Paper No. 07/2011, Deutsche Bundesbank Eurosystem: Frankfurt am Main.

Kennedy, P., 1981. Estimation with correctly interpreted dummy variables in semi-logarithmic equations. The American Economic Review 71, 801.

Lang, M.H., Shackelford, D.A., 2000. Capitalization of capital gains taxes: evidence from stock price reactions to the 1997 rate reduction. Journal of Public Economics 76, 69-85.

Madrian, B.C., Shea, D.F., 2001. The power of suggestion: Inertia in 401(k) participation and savings behavior. The Quarterly Journal of Economics 116, 1149-1187.

Shackelford, D.A., Verrechia, R., 2002. Intertemporal tax discontinuities. Journal of Accounting Research 40, 205-222.

Starks, L.T., Yong, L., Zheng, L., 2006. Tax-loss selling and the January effect: Evidence from municipal bonds-closed funds. The Journal of Finance 61, 3049-3067.

Thaler, R.H., Bernartzi, S., 2004. Save more tomorrow: Using behavioral economics to increase employee saving. Journal of Political Economy 112, S164-S187.

Van Nieuwerburgh, S., Veldkamp, L., 2009. Information immobility and the home bias puzzle. The Journal of Finance 64, 1187-1215.

Voeller, D., Müller, J., 2011. Investor's reaction to a reform of corporate income taxation. Working Paper, Mannheim/Graz. 


\section{Tables}

TABLE 1: German capital gains tax reform 2009

\begin{tabular}{|c|c|c|c|}
\hline & \multicolumn{2}{|c|}{$\begin{array}{l}\text { acquisition before } \\
\text { 2009-01-01 }\end{array}$} & $\begin{array}{l}\text { acquisition after } \\
\text { 2009-01-01 }\end{array}$ \\
\hline holding period & $<1$ year & $>1$ year & no relevance \\
\hline $\begin{array}{l}\text { percentage of capital gain } \\
\text { taxable }\end{array}$ & $50 \%$ & $0 \%$ & $100 \%$ \\
\hline taxation & $0.5 \cdot \tau^{i} \cdot\left(1+\tau^{s}\right)$ & tax exempt & $\tau^{c} \cdot\left(1+\tau^{s}\right)$ \\
\hline
\end{tabular}

tax rate on capital gains depending on personal income tax rates

\begin{tabular}{l|l|l|l} 
& & & \\
$25 \%$ & $13.19 \%$ & $0 \%$ & $26.38 \%$ \\
$35 \%$ & $18.46 \%$ & $0 \%$ & $26.38 \%$ \\
$45 \%$ & $23.74 \%$ & $0 \%$ & $26.38 \%$ \\
\hline
\end{tabular}

$\tau^{i}$ progressive personal income tax rate varying from $0 \%$ to $45 \%$

$\tau^{c}$ general capital gains tax rate, $25 \%$

$\tau^{s}$ solidarity tax surcharge rate, $5.5 \%$

Our analysis is based on the following assumptions: The taxpayer is resident in Germany and liable to unlimited taxation in Germany, shares are qualified as private assets, the participation quota never exceeded $1 \%$ over the last 5 years, no consideration of individual tax-free amounts. 
TABLE 2: Descriptive statistics

\begin{tabular}{lrrrrrrrrr}
\hline & \multicolumn{3}{c}{ German stock exchange } & \multicolumn{3}{c}{ French stock exchange } & \multicolumn{3}{c}{ UK Stock exchange } \\
\hline Observations & \multicolumn{3}{c}{52,317} & \multicolumn{3}{c}{68,473} & & \multicolumn{2}{c}{58,797} \\
\hline Variable & Mean & Median & $\begin{array}{c}\text { Standard } \\
\text { deviation }\end{array}$ & Mean & Median & $\begin{array}{r}\text { Standard } \\
\text { deviation }\end{array}$ & Mean & Median & $\begin{array}{r}\text { Standard } \\
\text { deviation }\end{array}$ \\
\hline Asset price & 30.60 & 12.03 & 79.50 & 51.51 & 19.96 & 230.80 & 455.97 & 274.00 & 631.48 \\
Daily return (\%) & 0.02 & 0.00 & 3.81 & -.17 & 0.00 & 3.20 & -0.03 & 0.00 & 3.56 \\
Trading volume (1,000) & 728.57 & 23.2 & $3,833.42$ & 506.26 & 5.70 & $2,027.76$ & $4,156.08$ & 749.00 & $16,368.07$ \\
Market value (in Mio.) & $3,029.20$ & 187.22 & $9,661.94$ & $3,401.27$ & 196.42 & $11,419.44$ & $3,972.31$ & 607.72 & $11,873.39$ \\
Book value (in Mio.) & $1,903.92$ & 145.01 & $5,967.06$ & $2,325.84$ & 179.35 & $7,503.35$ & $2,279.56$ & 291.90 & $8,170.69$ \\
EBITDA (in Mio.) & 815.19 & 44.86 & $2,742.28$ & 712.77 & 45.06 & $2,452.99$ & 806.04 & 97.35 & $2,704.57$ \\
\hline Aset & & & & & & & & &
\end{tabular}

Asset prices, market values, book values and EBITDA are reported in local currency ( $€$ or British pounds). Trading volume is reported in share trades per day. Daily return is the relative change in share prices compared to the asset price of the preceding year.

TABLE 3: Descriptive statistics of regression variables

\begin{tabular}{lccrrrrrrr}
\hline & \multicolumn{3}{c}{ German stock exchange } & \multicolumn{3}{c}{ French stock exchange } & \multicolumn{3}{c}{ UK Stock exchange } \\
\hline Observations & \multicolumn{3}{c}{52,317} & \multicolumn{2}{c}{68,473} & & \multicolumn{2}{c}{58,797} \\
\hline Variable & Mean & Median & $\begin{array}{r}\text { Standard } \\
\text { deviation }\end{array}$ & Mean & Median & $\begin{array}{r}\text { Standard } \\
\text { deviation }\end{array}$ & Mean & $\begin{array}{r}\text { Median Standard } \\
\text { deviation }\end{array}$ \\
\hline Asset price (LN) & 2.4592 & 2.4870 & 1.3519 & 3.0133 & 3.1271 & 1.3404 & 5.7035 & 5.7430 & 1.0902 \\
Daily return (\%) & 0.0176 & 0.0000 & 3.8084 & -0.1670 & 0.0000 & 3.2016 & -0.0292 & 0.0000 & 3.5633 \\
Trading volume (LN) & 3.3716 & 3.148 & 2.7207 & 2.2542 & 1.8245 & 3.1564 & 6.2791 & 6.6020 & 2.3962 \\
Market value (LN) & 5.6577 & 5.3178 & 2.2004 & 5.7886 & 5.4885 & 2.2243 & 6.7718 & 6.6022 & 1.6361 \\
Book value (LN) & 5.1720 & 4.9202 & 2.1071 & 5.4236 & 5.2105 & 2.1658 & 5.9806 & 5.7281 & 1.7239 \\
EBITDA (LN) & 4.0460 & 3.7856 & 2.3797 & 4.0342 & 3.8762 & 2.4108 & 4.8746 & 4.6540 & 1.7377 \\
\hline Descriptive statistics of major regression variables. & & & & & & & & &
\end{tabular}

Descriptive statistics of major regression variables. 
TABLE 4: Regression results (one trading week)

\begin{tabular}{|c|c|c|c|c|c|c|}
\hline Model & 1 & 2 & 3 & 4 & 5 & 6 \\
\hline Dependent variable & Asset price & Asset price & Daily return & Daily return & Volume & Volume \\
\hline Before (1W) & $\begin{array}{r}0.0148 * * * \\
(0.00157)\end{array}$ & $\begin{array}{r}0.0146 * * * \\
(0.00146)\end{array}$ & $\begin{array}{r}0.00593^{* * * *} \\
(0.000294)\end{array}$ & $\begin{array}{r}0.00593 * * * \\
(0.000294)\end{array}$ & $\begin{array}{r}-0.361 * * * \\
(0.0181)\end{array}$ & $\begin{array}{r}-0.361 * * * \\
(0.0181)\end{array}$ \\
\hline Before Germany (1W) & $\begin{array}{r}0.0128 * * * \\
(0.00311)\end{array}$ & $\begin{array}{r}0.0138 * * * \\
(0.00283)\end{array}$ & $\begin{array}{r}-0.00209 * * * \\
(0.000558)\end{array}$ & $\begin{array}{r}-0.00210 * * * \\
(0.000558)\end{array}$ & $\begin{array}{r}0.0368 \\
(0.0302)\end{array}$ & $\begin{array}{r}0.0371 \\
(0.0302)\end{array}$ \\
\hline Before 0809 (1W) & $\begin{array}{r}-0.0250 * * * \\
(0.00447)\end{array}$ & $\begin{array}{r}-0.0250 * * * \\
(0.00436)\end{array}$ & $\begin{array}{r}-0.00357 * * * \\
(0.000696)\end{array}$ & $\begin{array}{r}-0.00357 * * * \\
(0.000696)\end{array}$ & $\begin{array}{r}0.173 * * * \\
(0.0263)\end{array}$ & $\begin{array}{r}0.173 * * * \\
(0.0263)\end{array}$ \\
\hline Before DiD (1W) & $\begin{array}{r}0.0418 * * * \\
(0.00810)\end{array}$ & $\begin{array}{r}0.0324 * * * \\
(0.00744)\end{array}$ & $\begin{array}{r}0.0210 * * * \\
(0.00179)\end{array}$ & $\begin{array}{r}0.0210 * * * \\
(0.00180)\end{array}$ & $\begin{array}{r}0.802 * * * \\
(0.0457)\end{array}$ & $\begin{array}{r}0.800 * * * \\
(0.0457)\end{array}$ \\
\hline After $(1 \mathrm{~W})$ & $\begin{array}{r}0.0270 * * * \\
(0.00148)\end{array}$ & $\begin{array}{r}0.0269 * * * \\
(0.00138)\end{array}$ & $\begin{array}{r}0.00158 * * * \\
(0.000315)\end{array}$ & $\begin{array}{r}0.00158 * * * \\
(0.000315)\end{array}$ & $\begin{array}{r}-0.106 * * * \\
(0.0141)\end{array}$ & $\begin{array}{r}-0.105 * * * \\
(0.0141)\end{array}$ \\
\hline After Germany (1W) & $\begin{array}{r}0.0126 * * * \\
(0.00331)\end{array}$ & $\begin{array}{r}0.0118 * * * \\
(0.00294)\end{array}$ & $\begin{array}{l}0.00142 * * \\
(0.000634)\end{array}$ & $\begin{array}{l}0.00142 * * \\
(0.000635)\end{array}$ & $\begin{array}{r}-0.0512 * * \\
(0.0247)\end{array}$ & $\begin{array}{r}-0.0513 * * \\
(0.0247)\end{array}$ \\
\hline After 0809 (1W) & $\begin{array}{r}0.0256^{* * * *} \\
(0.00401)\end{array}$ & $\begin{array}{r}0.0258 * * * \\
(0.00408)\end{array}$ & $\begin{array}{l}0.0112 * * * \\
(0.000849)\end{array}$ & $\begin{array}{l}0.0112 * * * \\
(0.000848)\end{array}$ & $\begin{array}{r}-0.0162 \\
(0.0278)\end{array}$ & $\begin{array}{r}-0.0163 \\
(0.0278)\end{array}$ \\
\hline After DiD (1W) & $\begin{array}{r}0.0293 * * * \\
(0.00800)\end{array}$ & $\begin{array}{r}0.0319 * * * \\
(0.00794)\end{array}$ & $\begin{array}{r}-0.0125 * * * \\
(0.00165)\end{array}$ & $\begin{array}{r}-0.0125 * * * \\
(0.00165) \\
\end{array}$ & $\begin{array}{c}-0.114 * * \\
(0.0462)\end{array}$ & $\begin{array}{r}-0.113 * * \\
(0.0462) \\
\end{array}$ \\
\hline EBITDA & & $\begin{array}{r}0.0477 * * * \\
(0.0103)\end{array}$ & & $\begin{array}{r}0.000632 * * * \\
(0.000196)\end{array}$ & & $\begin{array}{r}0.0245 \\
(0.0251)\end{array}$ \\
\hline Market value & & $\begin{array}{r}0.724 * * * \\
(0.0298)\end{array}$ & & $\begin{array}{r}-0.00380 * * * \\
(0.000408)\end{array}$ & & $\begin{array}{r}0.210^{* * *} \\
(0.0544)\end{array}$ \\
\hline Book value & & $\begin{array}{r}0.141 * * * \\
(0.0305)\end{array}$ & & $\begin{array}{r}0.000886^{* *} \\
(0.000372)\end{array}$ & & $\begin{array}{r}-0.0546 \\
(0.0594)\end{array}$ \\
\hline Constant & $\begin{array}{l}3.904 * * * \\
(0.00847)\end{array}$ & $\begin{array}{r}-1.604 * * * \\
(0.224)\end{array}$ & $\begin{array}{r}-0.00302 * * * \\
(8.49 \mathrm{e}-05)\end{array}$ & $\begin{array}{r}0.0127 * * * \\
(0.00308)\end{array}$ & $\begin{array}{c}4.216^{* * *} \\
(0.0126)\end{array}$ & $\begin{array}{r}2.661 * * * \\
(0.462)\end{array}$ \\
\hline Stock fixed effects & YES & YES & YES & YES & YES & $\overline{\text { YES }}$ \\
\hline Market-year fixed effects & YES & YES & YES & YES & YES & YES \\
\hline Industry-year fixed effects & NO & YES & NO & YES & NO & YES \\
\hline Number of observations & 179,587 & 179,587 & 179,587 & 179,587 & 179,587 & 179,587 \\
\hline Number of assets/firms & 1,266 & 1,266 & 1,266 & 1,266 & 1,266 & 1,266 \\
\hline Within $\mathrm{R}^{2}$ & 0.490 & 0.728 & 0.00802 & 0.00865 & 0.0590 & 0.0616 \\
\hline Overall $\mathrm{R}^{2}$ & 0.0435 & 0.398 & 0.00808 & 0.00217 & 0.00639 & 0.411 \\
\hline \multicolumn{7}{|c|}{$\begin{array}{l}\text { Dependent variables: logarithm of asset price, daily return (in percentage points) and logarithm of trading volume (in } \\
\text { thousands). Estimates are calculated by OLS with stock fixed effects. Heteroscedasticity-robust standard errors are } \\
\text { clustered on the asset level and documented in parentheses; } * * / * * / * \text { indicate statistical significance on the } 1 \% / 5 \% / \\
10 \% \text { level. }\end{array}$} \\
\hline
\end{tabular}


TABLE 5: Regression results (two trading days)

\begin{tabular}{|c|c|c|c|c|c|c|}
\hline Model & 1 & 2 & 3 & 4 & 5 & 6 \\
\hline Dependent variable & Asset price & Asset price & Daily return & Daily return & Volume & Volume \\
\hline Before (2D) & $\begin{array}{r}0.0188 * * * \\
(0.00161)\end{array}$ & $\begin{array}{r}0.0189 * * * \\
(0.00145)\end{array}$ & $\begin{array}{r}0.00640 * * * \\
(0.000407)\end{array}$ & $\begin{array}{r}0.00640 * * * \\
(0.000406)\end{array}$ & $\begin{array}{r}-0.744 * * * \\
(0.0231)\end{array}$ & $\begin{array}{r}-0.744 * * * \\
(0.0231)\end{array}$ \\
\hline Before Germany (2D) & $\begin{array}{r}0.00884 * * \\
(0.00368)\end{array}$ & $\begin{array}{r}0.00912 * * * \\
(0.00313)\end{array}$ & $\begin{array}{r}-0.00274 * * * \\
(0.000846)\end{array}$ & $\begin{array}{r}-0.00275 * * * \\
(0.000846)\end{array}$ & $\begin{array}{r}0.386 * * * \\
(0.0416)\end{array}$ & $\begin{array}{r}0.386 * * * \\
(0.0416)\end{array}$ \\
\hline Before 0809 (2D) & $\begin{array}{r}-0.0218 * * * \\
(0.00440)\end{array}$ & $\begin{array}{r}-0.0220 * * * \\
(0.00422)\end{array}$ & $\begin{array}{r}0.00545^{* * *} \\
(0.00122)\end{array}$ & $\begin{array}{r}0.00545^{* * * *} \\
(0.00122)\end{array}$ & $\begin{array}{r}0.123 * * * \\
(0.0352)\end{array}$ & $\begin{array}{r}0.123 * * * \\
(0.0351)\end{array}$ \\
\hline Before DiD (2D) & $\begin{array}{r}0.0704 * * * \\
(0.00887)\end{array}$ & $\begin{array}{r}0.0610 * * * \\
(0.00791)\end{array}$ & $\begin{array}{r}0.0213 * * * \\
(0.00245)\end{array}$ & $\begin{array}{r}0.0214 * * * \\
(0.00245)\end{array}$ & $\begin{array}{r}0.924 * * * \\
(0.0582)\end{array}$ & $\begin{array}{r}0.921 * * * \\
(0.0583)\end{array}$ \\
\hline After (2D) & $\begin{array}{r}0.0310^{* * * *} \\
(0.00149)\end{array}$ & $\begin{array}{r}0.0312 * * * \\
(0.00136)\end{array}$ & $\begin{array}{r}0.00484 * * * \\
(0.000475)\end{array}$ & $\begin{array}{r}0.00484 * * * \\
(0.000475)\end{array}$ & $\begin{array}{r}-0.225 * * * \\
(0.0183)\end{array}$ & $\begin{array}{r}-0.225 * * * \\
(0.0183)\end{array}$ \\
\hline After Germany (2D) & $\begin{array}{r}0.00768 * * \\
(0.00365)\end{array}$ & $\begin{array}{r}0.00603 * * \\
(0.00294)\end{array}$ & $\begin{array}{c}0.00185^{*} \\
(0.00105)\end{array}$ & $\begin{array}{c}0.00185^{*} \\
(0.00105)\end{array}$ & $\begin{array}{r}0.0112 \\
(0.0298)\end{array}$ & $\begin{array}{r}0.0108 \\
(0.0298)\end{array}$ \\
\hline After 0809 (2D) & $\begin{array}{r}0.00605 \\
(0.00412)\end{array}$ & $\begin{array}{c}0.00735^{*} \\
(0.00415)\end{array}$ & $\begin{array}{r}0.0187 * * * \\
(0.00137)\end{array}$ & $\begin{array}{r}0.0187 * * * \\
(0.00137)\end{array}$ & $\begin{array}{r}-0.169 * * * \\
(0.0343)\end{array}$ & $\begin{array}{r}-0.168 * * * \\
(0.0343)\end{array}$ \\
\hline After DiD (2D) & $\begin{array}{r}0.0480 * * * \\
(0.00861)\end{array}$ & $\begin{array}{r}0.0459 * * * \\
(0.00817) \\
\end{array}$ & $\begin{array}{r}-0.0174 * * * \\
(0.00261)\end{array}$ & $\begin{array}{r}-0.0174 * * * \\
(0.00261) \\
\end{array}$ & $\begin{array}{r}-0.0376 \\
(0.0587)\end{array}$ & $\begin{array}{r}-0.0386 \\
(0.0588) \\
\end{array}$ \\
\hline EBITDA & & $\begin{array}{r}0.0477 * * * \\
(0.0103)\end{array}$ & & $\begin{array}{r}0.000631 * * * \\
(0.000194)\end{array}$ & & $\begin{array}{r}0.0246 \\
(0.0251)\end{array}$ \\
\hline Market value & & $\begin{array}{r}0.724 * * * \\
(0.0298)\end{array}$ & & $\begin{array}{r}-0.00378 * * * \\
(0.000407)\end{array}$ & & $\begin{array}{r}0.211 * * * \\
(0.0544)\end{array}$ \\
\hline Book value & & $\begin{array}{r}0.141 * * * \\
(0.0305)\end{array}$ & & $\begin{array}{r}0.000883^{* *} \\
(0.000371)\end{array}$ & & $\begin{array}{l}-0.0545 \\
(0.0593)\end{array}$ \\
\hline Constant & $\begin{array}{l}3.907 * * * \\
(0.00847)\end{array}$ & $\begin{array}{r}-1.601 * * * \\
(0.224)\end{array}$ & $\begin{array}{r}-0.00278 * * * \\
(8.20 \mathrm{e}-05)\end{array}$ & $\begin{array}{r}0.0129 * * * \\
(0.00307)\end{array}$ & $\begin{array}{c}4.205 * * * \\
(0.0126)\end{array}$ & $\begin{array}{r}2.646^{* * * *} \\
(0.462)\end{array}$ \\
\hline Stock fixed effects & YES & YES & YES & YES & YES & $\overline{\text { YES }}$ \\
\hline Market-year fixed effects & YES & YES & YES & YES & YES & YES \\
\hline Industry-year fixed effects & NO & YES & NO & YES & NO & YES \\
\hline Number of observations & 179,587 & 179,587 & 179,587 & 179,587 & 179,587 & 179,587 \\
\hline Number of assets/firms & 1,266 & 1,266 & 1,266 & 1,266 & 1,266 & 1,266 \\
\hline Within $\mathrm{R}^{2}$ & 0.490 & 0.727 & 0.00929 & 0.00991 & 0.0639 & 0.0665 \\
\hline Overall $\mathrm{R}^{2}$ & 0.0439 & 0.399 & 0.00934 & 0.00275 & 0.00661 & 0.407 \\
\hline \multicolumn{7}{|c|}{$\begin{array}{l}\text { Dependent variables: logarithm of asset price, daily return (in percentage points) and logarithm of trading volume (in } \\
\text { thousands). Estimates are calculated by OLS with stock fixed effects. Heteroscedasticity-robust standard errors are } \\
\text { clustered on the asset level and documented in parentheses; } * * / * * / * \text { indicate statistical significance on the } 1 \% / 5 \% / \\
10 \% \text { level. }\end{array}$} \\
\hline
\end{tabular}


TABLE 6: Regression results (two trading days and one trading week)

\begin{tabular}{|c|c|c|c|c|c|c|}
\hline Model & 1 & 2 & 3 & 4 & 5 & 6 \\
\hline Dependent variable & Asset price & Asset price & Daily return & Daily return & Volume & Volume \\
\hline \multirow[t]{2}{*}{ Before (2D) } & $0.0101 * * *$ & $0.0105 * * *$ & $0.00121 * *$ & $0.00121 * *$ & $-0.669 * * *$ & $-0.669 * * *$ \\
\hline & $(0.00100)$ & $(0.000915)$ & $(0.000593)$ & $(0.000592)$ & $(0.0244)$ & $(0.0244)$ \\
\hline \multirow[t]{2}{*}{ Before Germany (2D) } & -0.00431 & $-0.00534 * *$ & -0.00113 & -0.00114 & $0.577 * * *$ & $0.577 * * *$ \\
\hline & $(0.00337)$ & $(0.00241)$ & $(0.00113)$ & $(0.00113)$ & $(0.0417)$ & $(0.0417)$ \\
\hline \multirow[t]{2}{*}{ Before 0809 (2D) } & $0.00603 * *$ & $0.00556^{* *}$ & $0.0147 * * *$ & $0.0147 * * *$ & -0.0366 & -0.0365 \\
\hline & $(0.00279)$ & $(0.00245)$ & $(0.00163)$ & $(0.00163)$ & $(0.0374)$ & $(0.0374)$ \\
\hline \multirow[t]{2}{*}{ Before DiD (2D) } & $0.0518 * * *$ & $0.0513 * * *$ & 0.00210 & 0.00212 & $0.244 * * *$ & $0.243 * * *$ \\
\hline & $(0.00651)$ & $(0.00558)$ & $(0.00322)$ & $(0.00322)$ & (0.0619) & (0.0620) \\
\hline \multirow[t]{2}{*}{ After (2D) } & $0.00967 * * *$ & $0.0100 * * *$ & $0.00582 * * *$ & $0.00582 * * *$ & $-0.208 * * *$ & $-0.207 * * *$ \\
\hline & $(0.00110)$ & $(0.000991)$ & $(0.000580)$ & $(0.000581)$ & $(0.0210)$ & (0.0209) \\
\hline \multirow[t]{2}{*}{ After Germany (2D) } & $-0.00544 *$ & $-0.00673^{* * *}$ & 0.000771 & 0.000766 & $0.0758 * *$ & $0.0753^{* *}$ \\
\hline & $(0.00315)$ & $(0.00231)$ & $(0.00135)$ & $(0.00135)$ & $(0.0358)$ & $(0.0358)$ \\
\hline \multirow[t]{2}{*}{ After 0809 (2D) } & $-0.0314 * * *$ & $-0.0296 * * *$ & $0.0122 * * *$ & $0.0122 * * *$ & $-0.230 * * *$ & $-0.229 * * *$ \\
\hline & $(0.00273)$ & $(0.00251)$ & $(0.00179)$ & $(0.00179)$ & $(0.0389)$ & $(0.0389)$ \\
\hline \multirow[t]{2}{*}{ After DiD (2D) } & $0.0338 * * *$ & $0.0255 * * *$ & $-0.00673 * *$ & $-0.00667 * *$ & $0.181 * * *$ & $0.178 * * *$ \\
\hline & $(0.00743)$ & $(0.00620)$ & $(\mathbf{0 . 0 0 3 3 5 )}$ & $(\mathbf{0 . 0 0 3 3 4 )}$ & $(0.0682)$ & $(0.0683)$ \\
\hline \multirow[t]{2}{*}{ Before $(1 \mathrm{~W})$} & $0.0105^{* * *}$ & $0.0102 * * *$ & $0.00542 * * *$ & $0.00542 * * *$ & $-0.0808 * * *$ & $-0.0809 * * *$ \\
\hline & $(0.00159)$ & $(0.00151)$ & $(0.000421)$ & $(0.000421)$ & $(0.0200)$ & $(0.0200)$ \\
\hline \multirow[t]{2}{*}{ Before Germany (1W) } & $0.0148 * * *$ & $0.0161 * * *$ & $-0.00161 * *$ & $-0.00162 * *$ & $-0.207 * * *$ & $-0.206 * * *$ \\
\hline & $(0.00329)$ & $(0.00289)$ & $(0.000744)$ & $(0.000744)$ & $(0.0316)$ & $(0.0316)$ \\
\hline \multirow[t]{2}{*}{ Before $0809(1 \mathrm{~W})$} & $-0.0272 * * *$ & $-0.0270 * * *$ & $-0.00937 * * *$ & $-0.00937 * * *$ & $0.173 * * *$ & $0.173 * * *$ \\
\hline & $(0.00465)$ & $(0.00451)$ & $(0.000946)$ & $(0.000946)$ & $(0.0292)$ & $(0.0292)$ \\
\hline \multirow[t]{2}{*}{ Before DiD (1W) } & $0.0201 * *$ & 0.0110 & $0.0199 * * *$ & $0.0199 * * *$ & $0.718 * * *$ & $0.716 * * *$ \\
\hline & $(0.00818)$ & $(0.00753)$ & $(0.00235)$ & $(\mathbf{0 . 0 0 2 3 5})$ & $(0.0514)$ & $(0.0514)$ \\
\hline \multirow[t]{2}{*}{ After (1W) } & $0.0231 * * *$ & $0.0229 * * *$ & $-0.000752 *$ & $-0.000750 *$ & -0.0225 & -0.0225 \\
\hline & $(0.00156)$ & $(0.00146)$ & $(0.000384)$ & $(0.000384)$ & $(0.0165)$ & $(0.0165)$ \\
\hline \multirow[t]{2}{*}{ After Germany (1W) } & $0.0148 * * *$ & $0.0144 * * *$ & 0.00107 & 0.00107 & $-0.0806^{* * *}$ & $-0.0806 * * *$ \\
\hline & $(0.00352)$ & $(0.00315)$ & $(0.000810)$ & $(0.000811)$ & $(0.0301)$ & (0.0301) \\
\hline \multirow[t]{2}{*}{ After $0809(1 \mathrm{~W})$} & $0.0381 * * *$ & $0.0376 * * *$ & $0.00634 * * *$ & $0.00634 * * *$ & $0.0743 * *$ & $0.0740 * *$ \\
\hline & $(0.00407)$ & $(0.00409)$ & $(0.00112)$ & $(0.00112)$ & $(0.0327)$ & $(0.0327)$ \\
\hline \multirow[t]{2}{*}{ After DiD (1W) } & 0.0158* & $0.0217 * * *$ & $-0.0100 * * *$ & $-0.0101 * * *$ & $-0.182 * * *$ & $-0.180 * * *$ \\
\hline & $(0.00854)$ & $(0.00832)$ & (0.00212) & $(0.00212)$ & $(0.0550)$ & $(0.0551)$ \\
\hline \multirow[t]{2}{*}{ EBITDA } & & $0.0477 * * *$ & & $0.000631 * * *$ & & 0.0246 \\
\hline & & (0.0103) & & (0.000196) & & $(0.0251)$ \\
\hline \multirow[t]{2}{*}{ Market value } & & $0.724 * * *$ & & $-0.00380^{* * *}$ & & $0.210^{* * *}$ \\
\hline & & $(0.0298)$ & & $(0.000407)$ & & $(0.0544)$ \\
\hline \multirow[t]{2}{*}{ Book value } & & $0.141 * * *$ & & $0.000881 * *$ & & -0.0545 \\
\hline & & $(0.0305)$ & & $(0.000371)$ & & $(0.0593)$ \\
\hline \multirow[t]{2}{*}{ Constant } & $3.904 * * *$ & $-1.604 * * *$ & $-0.00302 * * *$ & $0.0127 * * *$ & $4.215 * * *$ & $2.661 * * *$ \\
\hline & $(0.00847)$ & $(0.224)$ & $(8.49 \mathrm{e}-05)$ & $(0.00308)$ & $(0.0126)$ & $(0.462)$ \\
\hline Stock fixed effects & YES & YES & YES & YES & YES & YES \\
\hline Market-year fixed effects & YES & YES & YES & YES & YES & YES \\
\hline Industry-year fixed effects & NO & YES & $\mathrm{NO}$ & YES & $\mathrm{NO}$ & YES \\
\hline Number of observations & 179,587 & 179,587 & 179,587 & 179,587 & 179,587 & 179,587 \\
\hline Number of stocks & 1,266 & 1,266 & 1,266 & 1,266 & 1,266 & 1,266 \\
\hline Within $\mathrm{R}^{2}$ & 0.491 & 0.728 & 0.0112 & 0.0119 & 0.0671 & 0.0697 \\
\hline Overall $\mathrm{R}^{2}$ & 0.0435 & 0.398 & 0.0113 & 0.00364 & 0.00707 & 0.405 \\
\hline
\end{tabular}




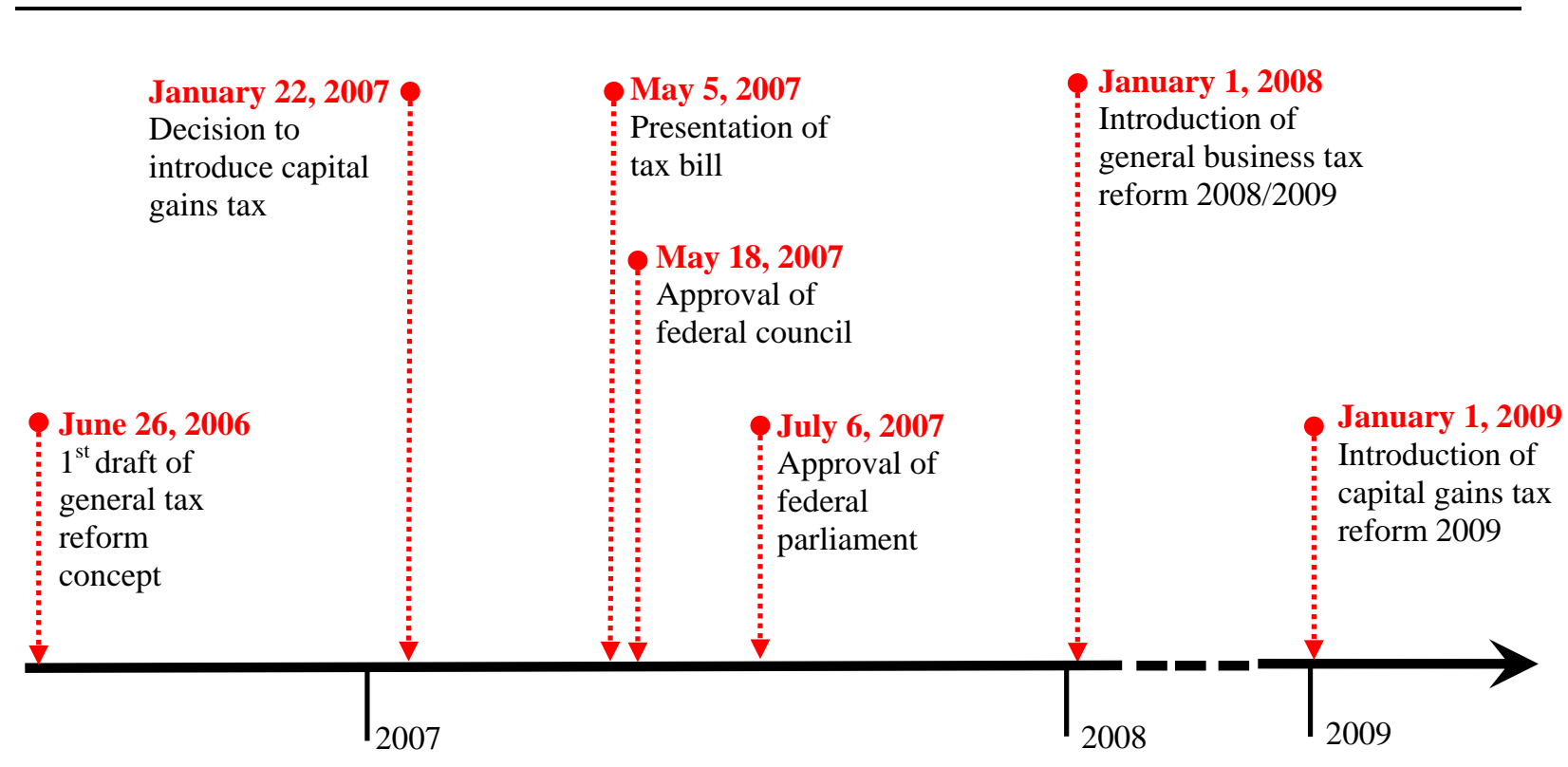

FIGURE 2: Abnormal trading volumes 2008/2009

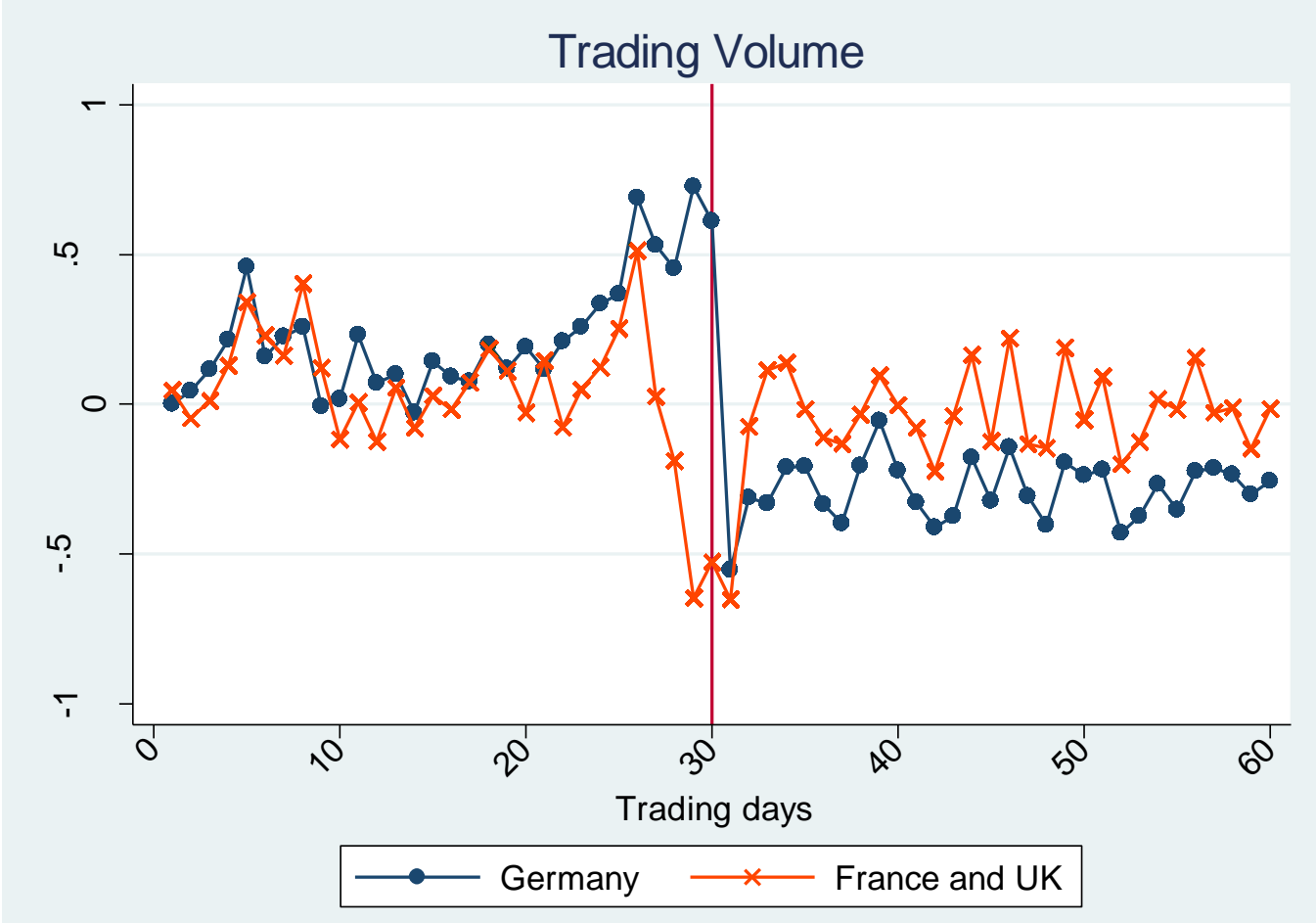


FIGURE 3: Abnormal daily returns 2008/2009

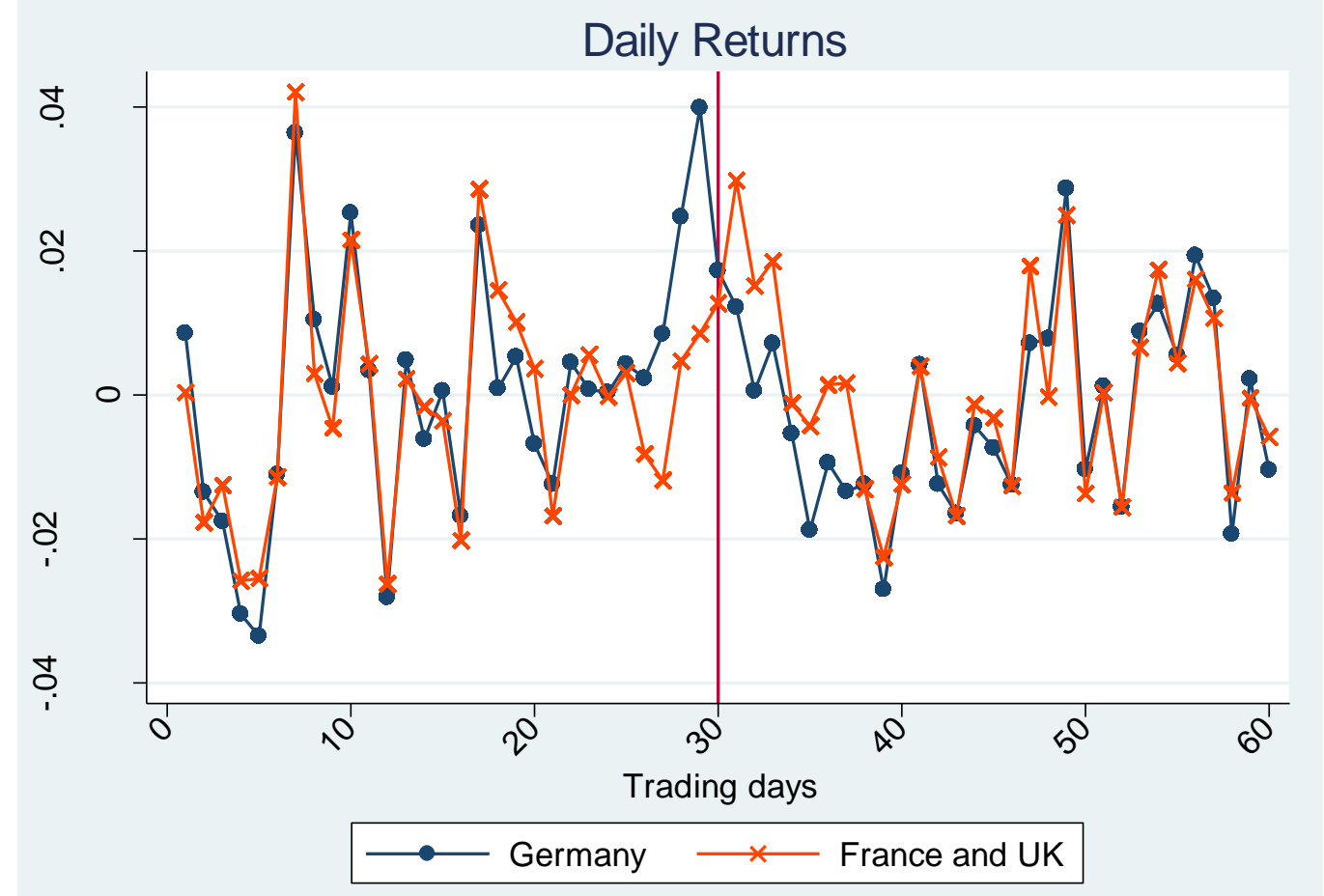

FIGURE 4: Abnormal asset prices 2008/2009

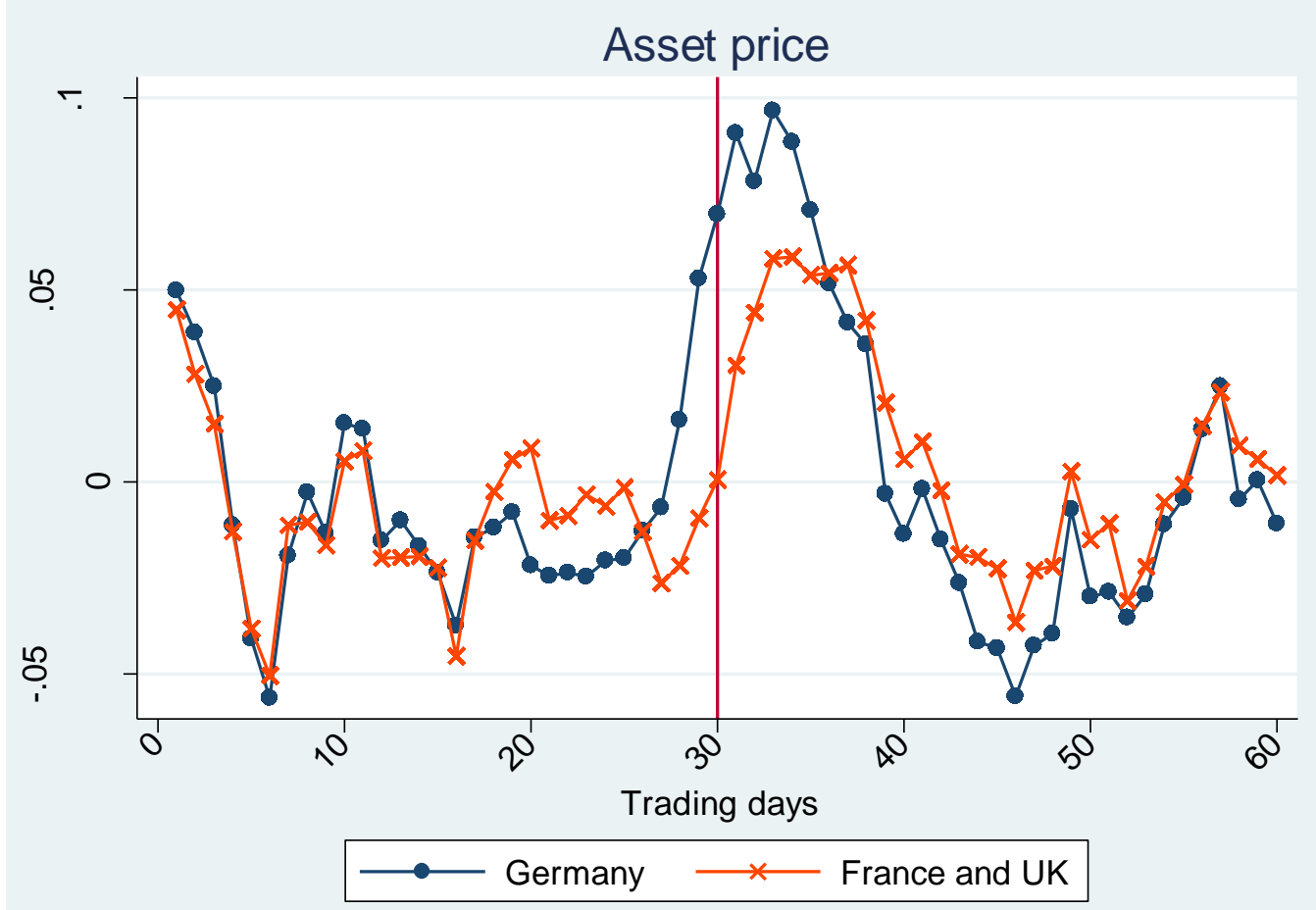

